\title{
Fluctuation of birch (Betula L.) pollen seasons in Poland
}

\author{
Małgorzata Puc ${ }^{1,2 *}$, Tomasz Wolski ${ }^{3}$, Irene Câmara Camacho4, Dorota Myszkowska ${ }^{5}$, Idalia Kasprzyk ${ }^{6}$, Łukasz \\ Grewling ${ }^{7}$, Małgorzata Nowak7 , Elżbieta Weryszko-Chmielewska ${ }^{8}, K^{2}$ rystyna Piotrowska-Weryszko9, \\ Kazimiera Chłopek ${ }^{10}$, Katarzyna Dąbrowska-Zapart ${ }^{10}$, Barbara Majkowska-Wojciechowska ${ }^{11}$, Zofia \\ Balwierz ${ }^{12}$, Małgorzata Malkiewicz ${ }^{13}$, Agnieszka Grinn-Gofrońn ${ }^{14}$, Alina Stacewicz ${ }^{12}$, Aleksandra Kruczek ${ }^{1,2}$, \\ Katarzyna Borycka ${ }^{6}$ \\ ${ }^{1}$ Department of Botany and Nature Conservation, Faculty of Biology, University of Szczecin, Felczaka 3c, 71-412 Szczecin, Poland \\ ${ }^{2}$ Molecular Biology and Biotechnology Center, Faculty of Biology, University of Szczecin, Wąska 13, 71-415 Szczecin, Poland \\ ${ }^{3}$ Physical Oceanography Laboratory, University of Szczecin, Mickiewicza 16, 70-383 Szczecin, Poland \\ ${ }^{4}$ Life Science Competence Centre, Madeira University, Campus Universitário da Penteada, 9000-390 Funchal, Portugal \\ ${ }^{5}$ Department of Clinical and Environmental Allergology, Jagiellonian University Medical College, Śniadeckich 10, 31-531 Cracow, Poland \\ ${ }^{6}$ Department of Environmental Biology, University of Rzeszów, Zelwerowicza 4, 35-601 Rzeszów, Poland \\ ${ }^{7}$ Laboratory of Aeropalynology, Faculty of Biology, Adam Mickiewicz University, Umultowska 89, 61-614 Poznań, Poland \\ ${ }^{8}$ Department of Botany, University of Life Sciences in Lublin, Akademicka 15, 20-950 Lublin, Poland \\ ${ }^{9}$ Department of General Ecology, University of Life Sciences in Lublin, Leszczyńskiego 58, 20-950 Lublin, Poland \\ ${ }^{10}$ Faculty of Earth Sciences, University of Silesia, Będzińska 60, 41-200 Sosnowiec, Poland \\ ${ }^{11}$ Department of Immunology, Rheumatology and Allergy, Medical University of Lodz, Pomorska 251, $92-213$ Łódź, Poland \\ ${ }^{12}$ Institute of Earth Science, University of Łódź, Narutowicza 88, 90-139 Łódź, Poland \\ ${ }^{13}$ Laboratory of Paleobotany, Department of Stratigraphical Geology, University of Wrocław, Cybulskiego 34, 50-205 Wrocław, Poland \\ ${ }^{14}$ Department of Plant Taxonomy and Phytogeography, Faculty of Biology, University of Szczecin, Wąska 13, 71- 415 Szczecin, Poland
}

\section{Abstract}

Birch pollen grains are one of the most important groups of atmospheric biological particles that induce allergic processes. The fluctuation pattern of birch pollen seasons in selected cities of Poland is presented. Measurements were performed by the volumetric method (Burkard and Lanzoni 2000 pollen samplers). The distributions of the data were not normal (Shapiro-Wilk test) and statistical error risk was estimated at a significance level of $\alpha=0.05$. Pollen season was defined as the period in which $95 \%$ of the annual total catch occurred. The linear trend for the selected features of the pollen season, skewness, kurtosis and coefficient of variation ( $V \%)$ were also analyzed. During the 12-14 years of study, the beginnings of birch pollen seasons were observed 7-14 days earlier, the ends were noted 5-10 days earlier, and the days with maximum values occurred 7-14 days earlier compared to the long-term data. The left-skewed distribution of the pollen season starts in most sampling sites confirms the short-lasting occurrence of pollen in the air. The threat of birch pollen allergens was high during the pollen seasons. If vegetation is highly diverse, flowering and pollen release are extended in time, spread over different weeks and occur at different times of the day. Flowering time and pollen release are affected by insolation, convection currents, wind, and turbulence. Therefore, pollen seasons are characterized by great inter-annual variability.

Keywords: Betula; pollen allergens; linear trend; pollen seasons; weather conditions; air pollution; Poland

\section{Introduction}

Birch pollen is the most common cause of allergy in April and May in Northern and Central Europe. Betula individuals produce profusely a large number of small oblate pollen grains with smooth surface which can be carried for hundreds or even thousands of kilometers by large air masses

\footnotetext{
* Corresponding author. Email: mapuc12@gmail.com
}

Handling Editor: Bożena Denisow
$[1,2]$. Birch trees are widespread across Poland. The genus Betula belongs to the Fagales order and the Betulaceae family which also comprises Corylus, Alnus, and Carpinus. Most species of birch grow in natural habitats. Betula pendula and $B$. pubescens occur most frequently; $B$. pendula is most often grown in gardens, parks, and streets as an ornamental tree; $B$. pubescens grows in moist habitats like swamp birch forests. The other species (B. humilis, B. nana, B. ×oycoviensis) are rare and occur in the south and east of Poland $[3,4]$.

The genus Betula range is restricted to the Northern Hemisphere, especially to the cooler parts of the temperate 
zone. Birch is essentially a pioneer taxon, light-demanding and with a high tolerance to climatic and soil conditions. Betula pendula is well adapted to continental conditions and tolerates summer high temperatures and very cold winters. Like B. pubescens, it is resistant to frost, developing buds that can tolerate down to $-4^{\circ} \mathrm{C}$. Due to their wide ecological amplitude, birches are components of almost all woodland communities from very dry dune pine forests to mires and from poor to fertile ash-elm forests. All birches are wind-pollinated and produce large amounts of light pollen, which enables its wide dispersal. The production of a single catkin may amount from 5.5 to 6 million pollen grains and its average weight is 6.1-10 $\mathrm{g}$ [5].

Consequently, birch pollen is abundant in the air in April and May, and it is a well-known major tree allergen in Central and Northern Europe [6]. It has an important impact on human health; cross reactions are observed between birch pollen allergens within one genus, between the genera, and also between the antigens of the pollen of birch and other plants within the families Corylaceae, Fagaceae, and Betulaceae as well as between the antigens of herbal plants, fruits, and vegetables [7-9]. About $20 \%$ of the population of Northern and Central Europe are allergic to birch pollen [6]. In the studies of Rapiejko et al. [10], patients sensitive to birch pollen developed first disease symptoms when subjected to more than 20 birch pollen grains in $1 \mathrm{~m}^{3}$ of air. A concentration higher than 155 grains in $1 \mathrm{~m}^{3}$ evoked dyspnea.

Although the relationships between birch pollen grains and meteorological factors are well documented in the references $[9,11,12]$, there are significantly fewer papers describing the most important parameters affecting the presence of pollen in the air and seasonal trends of birch airborne pollen in many pollen sampling sites.

The studies on the occurrence of birch pollen in the air above a given area enable the determination of differences in the intensity and time of pollination resulting from, inter alia, the influence of climatic changes and air pollution on plants [13].

The aim of the survey was to reveal the influence of meteorological factors and air pollution on the concentration of Betula pollen grains in the atmosphere of Szczecin as well as to determine seasonal long-term trends for the start and end of seasons, duration of pollen seasons, maximum value, date of occurrence of the seasonal maximum, and trends in the seasonal pollen index (SPI) in eight cites in Poland.

\section{Material and methods}

An analysis was performed of daily average Betula pollen counts. This taxon was chosen because of its allergic properties and the availability of data on clinical determination of the pollen threshold values at which allergy symptoms develop. The aerobiological monitoring was conducted in the years 2001-2014 in Szczecin, Poznań, Kraków, Sosnowiec, Lublin, in the years 2003-2014 in Wrocław and Łódź, and in the years 2001-2013 in Rzeszów. The climate of Szczecin is influenced by Atlantic air masses and the proximity of the Baltic Sea - winters are mild, summers are not very hot, and the weather often changes. Poznań and Łódź are situated in lowlands, while Wrocław and Lublin in highlands. Kraków, Sosnowiec and Rzeszów are located in southern Poland, and their climate is influenced by the Carpathian Mountains.

In these studies, a volumetric spore trap of the Hirst design was used [14] (Burkard and Lanzoni VPPS-2000). The trap worked continuously taking samples of airborne particles at a flow rate of $10 \mathrm{l}$ per min. The particles adhered to Melinex adhesive tape wrapped around a rotating drum. Pollen grains were stained with alkaline fuchsin. Every week, the Melinex tape was cut into seven segments corresponding to $24 \mathrm{~h}$ periods. A microscope slide was made for each day of sampling. Pollen grains were counted along 4 longitudinal transects, which were divided into $2 \mathrm{~mm}$ (1 hour) intervals or latitudinal transects; pollen grains were identified and counted using a light microscope at a magnification $\times 400$; the daily average pollen concentration was expressed as grains $/ \mathrm{m}^{3}$ per $24 \mathrm{~h}$.

The pollen season in particular years was defined as the period from which the sum of the daily mean pollen concentration reached $2.5 \%$ of the total sum until the time when the sum reached $97.5 \%$, i.e., the time with $95 \%$ of the whole pollen count (95\% method) [15].

The SPI was calculated as a total of daily average pollen counts in a given season [15].

The distributions of the data were not normal (Shapiro-Wilk test) and statistical error risk was estimated at a significance level of $P<0.05,0.01$, and 0.001. Mean, minimum and maximum values, standard deviation, variation coefficient, skewness, and kurtosis were calculated (Tab. 1). These analyses were conducted using Statistica ver. 11 [15]. The linear trend in the determination coefficient $\left(R^{2}\right)$ was calculated using Excel (MS Office 2010). Spearman's correlations between the linear trend and selected features of the pollen season (start and end of seasons, duration of pollen seasons, maximum value, date of occurrence of the seasonal maximum, and trends in the SPI were calculated using Statistica ver. 11 [16].

The degree of correlation between particular meteorological parameters, air pollution and the concentration of Betula in Szczecin was analyzed by non-parametric Spearman's correlation test (Tab. 2).

\section{Results}

\section{Characteristics of pollen seasons}

The start of the birch pollen season in the analyzed period occurred on average between the 10th and 14th of April, whereas the end of the season was observed on average between the 1st and 13th of May. The earliest birch pollen season was noted on the 12th of March in Łódź, where the latest end of the extreme season was observed, as well as on the 14th of June (a very high variation coefficient $V=$ $11.5 \%)$. The pollen seasons were relatively short; the duration of the seasons ranged on average from 22 days in Wrocław and Rzeszów to 33 days in Szczecin. The shortest seasons of ca. 1.5 week were found in Wrocław, Łódź, and Rzeszów. The longest season, which lasted two months, was noted in Łódź. The maximum difference in season length amounts 
Tab. 1 Characteristics of birch pollen seasons.

\begin{tabular}{|c|c|c|c|c|c|c|c|}
\hline \multirow[b]{2}{*}{ City } & \multicolumn{7}{|c|}{ Data from the period 2001-2014 } \\
\hline & Parameter & $\begin{array}{l}\text { Start of pollen } \\
\text { season }(95 \%)\end{array}$ & $\begin{array}{l}\text { End of pollen } \\
\text { season }(95 \%)\end{array}$ & $\begin{array}{c}\text { Duration } \\
\text { (days) }\end{array}$ & $\begin{array}{l}\text { Maximum } \\
\text { pollen count } \\
\left(\text { grains } / \mathbf{m}^{3}\right)\end{array}$ & $\begin{array}{c}\text { Date of } \\
\text { maximum } \\
\text { pollen count }\end{array}$ & $\begin{array}{c}\text { Seasonal } \\
\text { pollen index } \\
\text { (SPI) }\end{array}$ \\
\hline \multirow[t]{8}{*}{ Szczecin } & Mean & $10 \mathrm{IV}$ & $13 \mathrm{~V}$ & 33.36 & 2061.43 & $17 \mathrm{IV}$ & 10122.79 \\
\hline & Median & $9 \mathrm{IV}$ & $13 \mathrm{~V}$ & 34.00 & 1437.00 & $20 \mathrm{IV}$ & 8677.50 \\
\hline & Min. & $31 \mathrm{III}$ & $27 \mathrm{IV}$ & 19.00 & 455.00 & $8 \mathrm{IV}$ & 3070.00 \\
\hline & Max. & $24 \mathrm{IV}$ & $25 \mathrm{~V}$ & 51.00 & 5736.00 & $30 \mathrm{IV}$ & 22987.00 \\
\hline & $S D$ & 7.29 & 9.22 & 9.45 & 1524.29 & 6.36 & 5690.09 \\
\hline & $V(\%)$ & 7.23 & 6.93 & 28.33 & 73.94 & 5.79 & 56.21 \\
\hline & Skewness & 0.43 & -0.14 & 0.11 & 1.36 & -0.27 & 1.20 \\
\hline & Kurtosis & -0.54 & -1.15 & -0.60 & 1.10 & -0.85 & 0.95 \\
\hline \multirow[t]{8}{*}{ Poznań } & Mean & $12 \mathrm{IV}$ & $5 \mathrm{~V}$ & 23.50 & 1973.86 & $20 \mathrm{IV}$ & 11605.93 \\
\hline & Median & $12 \mathrm{IV}$ & $4 \mathrm{~V}$ & 24.00 & 1853.50 & $22 \mathrm{IV}$ & 10878.50 \\
\hline & Min. & $30 \mathrm{III}$ & $28 \mathrm{IV}$ & 15.00 & 241.00 & $8 \mathrm{IV}$ & 1783.00 \\
\hline & Max. & $23 \mathrm{IV}$ & $13 \mathrm{~V}$ & 30.00 & 4355.00 & $30 \mathrm{IV}$ & 24475.00 \\
\hline & $S D$ & 6.57 & 4.81 & 4.43 & 1190.38 & 6.01 & 6772.88 \\
\hline & $V(\%)$ & 6.44 & 3.86 & 18.86 & 60.31 & 5.47 & 58.36 \\
\hline & Skewness & -0.04 & 0.57 & -0.64 & 0.64 & -0.66 & 0.37 \\
\hline & Kurtosis & -0.11 & -0.57 & -0.11 & 0.05 & 0.50 & -0.81 \\
\hline \multirow[t]{8}{*}{ Wrocław } & Mean & $10 \mathrm{IV}$ & $1 \mathrm{~V}$ & 22.17 & 1613.83 & $17 \mathrm{IV}$ & 9103.58 \\
\hline & Median & $8 \mathrm{IV}$ & $1 \mathrm{~V}$ & 21.50 & 1539.00 & $18 \mathrm{IV}$ & 7665.00 \\
\hline & Min. & $30 \mathrm{III}$ & $25 \mathrm{IV}$ & 12.00 & 665.00 & $8 \mathrm{IV}$ & 3936.00 \\
\hline & Max. & $19 \mathrm{IV}$ & $9 \mathrm{~V}$ & 31.00 & 2562.00 & $23 \mathrm{IV}$ & 16038.00 \\
\hline & $S D$ & 6.54 & 4.01 & 5.87 & 578.63 & 5.51 & 4900.76 \\
\hline & $V(\%)$ & 6.58 & 3.32 & 26.50 & 35.85 & 5.15 & 53.83 \\
\hline & Skewness & 0.41 & 0.53 & -0.39 & 0.09 & -0.67 & 0.42 \\
\hline & Kurtosis & -0.73 & 0.41 & -0.57 & -0.55 & -0.98 & -1.75 \\
\hline \multirow[t]{8}{*}{ Kraków } & Mean & $11 \mathrm{IV}$ & $7 \mathrm{~V}$ & 27.79 & 821.81 & $18 \mathrm{IV}$ & 5631.25 \\
\hline & Median & $10 \mathrm{IV}$ & $8 \mathrm{~V}$ & 27.00 & 763.00 & $18 \mathrm{IV}$ & 4602.74 \\
\hline & Min. & 29 III & $25 \mathrm{IV}$ & 17.00 & 119.00 & $3 \mathrm{IV}$ & 1298.00 \\
\hline & Max. & $21 \mathrm{IV}$ & $17 \mathrm{~V}$ & 40.00 & 1837.71 & $2 \mathrm{~V}$ & 14267.17 \\
\hline & $S D$ & 6.80 & 5.99 & 7.29 & 567.08 & 7.13 & 4263.06 \\
\hline & $V(\%)$ & 6.76 & 4.71 & 26.23 & 69.00 & 6.59 & 75.70 \\
\hline & Skewness & -0.11 & -0.48 & 0.05 & 0.44 & -0.26 & 1.03 \\
\hline & Kurtosis & -0.10 & -0.03 & -1.13 & -0.89 & 0.89 & -0.10 \\
\hline \multirow[t]{8}{*}{ Sosnowiec } & Mean & $12 \mathrm{IV}$ & $6 \mathrm{~V}$ & 25.14 & 2635.93 & $20 \mathrm{IV}$ & 11258.64 \\
\hline & Median & $11 \mathrm{IV}$ & $5 \mathrm{~V}$ & 25.50 & 1710.00 & $19 \mathrm{IV}$ & 11113.00 \\
\hline & Min. & $31 \mathrm{III}$ & $28 \mathrm{IV}$ & 14.00 & 150.00 & $8 \mathrm{IV}$ & 1336.00 \\
\hline & Max. & $23 \mathrm{IV}$ & $20 \mathrm{~V}$ & 43.00 & 9967.00 & $2 \mathrm{~V}$ & 29050.00 \\
\hline & $S D$ & 7.04 & 5.49 & 8.08 & 2852.84 & 5.52 & 9349.90 \\
\hline & $V(\%)$ & 6.89 & 4.36 & 32.12 & 108.23 & 5.01 & 83.05 \\
\hline & Skewness & 0.19 & 1.25 & 0.54 & 1.56 & -0.02 & 0.67 \\
\hline & Kurtosis & -0.95 & 2.47 & 0.19 & 2.18 & 1.89 & -0.78 \\
\hline \multirow[t]{8}{*}{ Łódź } & Mean & $12 \mathrm{IV}$ & $8 \mathrm{~V}$ & 27.17 & 2803.67 & $18 \mathrm{IV}$ & 12689.42 \\
\hline & Median & $13 \mathrm{IV}$ & $5 \mathrm{~V}$ & 24.50 & 1991.00 & $20 \mathrm{IV}$ & 10798.00 \\
\hline & Min. & $12 \mathrm{III}$ & $12 \mathrm{IV}$ & 11.00 & 669.00 & $21 \mathrm{III}$ & 2949.00 \\
\hline & Max. & $22 \mathrm{IV}$ & $14 \mathrm{VI}$ & 64.00 & 8665.00 & $29 \mathrm{IV}$ & 29092.00 \\
\hline & $S D$ & 10.74 & 14.67 & 13.08 & 2349.43 & 9.85 & 8848.22 \\
\hline & $V(\%)$ & 10.58 & 11.49 & 48.14 & 83.80 & 9.15 & 69.73 \\
\hline & Skewness & -2.27 & 1.27 & 2.17 & 1.62 & -2.19 & 0.53 \\
\hline & Kurtosis & 6.53 & 4.17 & 6.31 & 2.63 & 6.23 & -1.10 \\
\hline \multirow[t]{4}{*}{ Lublin } & Mean & $14 \mathrm{IV}$ & $7 \mathrm{~V}$ & 23.71 & 3696.94 & $19 \mathrm{IV}$ & 15932.39 \\
\hline & Median & $14 \mathrm{IV}$ & $6 \mathrm{~V}$ & 23.50 & 2889.00 & $19 \mathrm{IV}$ & 14877.35 \\
\hline & Min. & $31 \mathrm{III}$ & $26 \mathrm{IV}$ & 14.00 & 521.00 & $8 \mathrm{IV}$ & 3132.40 \\
\hline & Max. & $23 \mathrm{IV}$ & $19 \mathrm{~V}$ & 34.00 & 12832.00 & $26 \mathrm{IV}$ & 33001.46 \\
\hline
\end{tabular}


Tab. 1 (continued)

\begin{tabular}{|c|c|c|c|c|c|c|c|}
\hline \multirow[b]{2}{*}{ City } & \multicolumn{7}{|c|}{ Data from the period $2001-2014$} \\
\hline & Parameter & $\begin{array}{c}\text { Start of pollen } \\
\text { season }(95 \%)\end{array}$ & $\begin{array}{l}\text { End of pollen } \\
\text { season }(95 \%)\end{array}$ & $\begin{array}{c}\text { Duration } \\
\text { (days) }\end{array}$ & $\begin{array}{c}\text { Maximum } \\
\text { pollen count } \\
\left(\text { grains } / \mathbf{m}^{3}\right)\end{array}$ & $\begin{array}{c}\text { Date of } \\
\text { maximum } \\
\text { pollen count }\end{array}$ & $\begin{array}{c}\text { Seasonal } \\
\text { pollen index } \\
(\mathrm{SPI})\end{array}$ \\
\hline \multirow{8}{*}{ Rzeszów } & $S D$ & 6.39 & 5.57 & 5.48 & 3473.02 & 5.31 & 10687.36 \\
\hline & $V(\%)$ & 6.14 & 4.39 & 23.12 & 93.94 & 4.87 & 67.08 \\
\hline & Kurtosis & 0.29 & 1.23 & 0.03 & 2.79 & -0.23 & -1.28 \\
\hline & Mean & $14 \mathrm{IV}$ & $5 \mathrm{~V}$ & 22.23 & 1344.69 & $21 \mathrm{IV}$ & 7358.31 \\
\hline & Median & $13 \mathrm{IV}$ & $4 \mathrm{~V}$ & 22.00 & 1197.00 & $22 \mathrm{IV}$ & 5489.00 \\
\hline & Min. & $5 \mathrm{IV}$ & $24 \mathrm{IV}$ & 11.00 & 168.00 & $9 \mathrm{IV}$ & 984.00 \\
\hline & Skewness & -0.05 & -0.24 & 0.76 & 0.41 & -0.62 & 0.56 \\
\hline & Kurtosis & -1.76 & -0.37 & 2.98 & -1.06 & 0.18 & -0.84 \\
\hline
\end{tabular}

Tab. 2 Spearman's rank correlation matrix for birch and whole data set in Szczecin (2001-2014).

\begin{tabular}{|c|c|c|c|c|c|c|c|c|c|c|}
\hline Variable & Betula & $\begin{array}{l}\text { Wind } \\
\text { speed }\end{array}$ & $\begin{array}{c}\text { Total } \\
\text { radiation }\end{array}$ & $\begin{array}{l}\text { Max } \\
\text { temp. }\end{array}$ & $\begin{array}{l}\text { Relative } \\
\text { humidity }\end{array}$ & $\mathbf{P M}_{10}$ & $\mathrm{SO}_{2}$ & NO & $\mathrm{NO}_{2}$ & $\mathrm{CO}$ \\
\hline Betula & & $*^{* *}$ & $* * *$ & $* * *+$ & $* * *$ & $* * *+$ & $*_{+}$ & $* * *+$ & $* *+$ & **+ \\
\hline Wind speed & $* *+$ & & $* * *$ & $* * *+$ & $* * *$ & $* *+$ & & $* *$ & *- & \\
\hline $\begin{array}{l}\text { Total } \\
\text { radiation }\end{array}$ & $* * *+$ & $* * *+$ & & $* * *+$ & $* * *$ & $* *+$ & $* * *+$ & $* * *+$ & $* * *+$ & $*_{+}$ \\
\hline Mean temp. & $* * *+$ & $* * * *$ & $* * * *+$ & & $* * *-$ & $* *+$ & $* * *+$ & $* * * *+$ & $* * *+$ & $* *+$ \\
\hline $\begin{array}{l}\text { Relative } \\
\text { humidity }\end{array}$ & $* * *$ & $* * *$ & $* * *$ & $* * *$ & & $* * *$ & $* * *_{-}$ & $* * *$ & *- & **_- \\
\hline $\mathbf{P M}_{10}$ & $* * *+$ & $* *+$ & $* *+$ & **+ & $* * *$ & & $* * *+$ & $* * *+$ & $* * *+$ & ${ }^{*}+$ \\
\hline $\mathrm{SO}_{2}$ & $*_{+}$ & & $* * *$ & $* * *+$ & $* * *$ & $* * *+$ & & $* * *+$ & & $* * *$ \\
\hline NO & $* * *+$ & $* *+$ & $* * *+$ & $* * *+$ & $* * *$ & $* * *+$ & $* * *+$ & & $* * *+$ & $* *+$ \\
\hline $\mathrm{NO}_{2}$ & $* *$ & $*_{-}$ & $* * *$ & $* * *+$ & *- & $* * *+$ & & $* * *+$ & & $* * *+$ \\
\hline $\mathrm{CO}$ & $* *+$ & & $*_{+}$ & $* *+$ & $* *_{-}$ & $*_{+}$ & $* * *$ & $* *+$ & $* * *+$ & \\
\hline
\end{tabular}

$P$-value: ${ }^{*} P<0.05 ;{ }^{* *} P<0.01 ;{ }^{* * *} P<0.001$; plus/minus - positive/negative correlation.

to even 34 days. In most cases, the lengths of the seasons differ by 11 days, on average (Tab. 1).

The distribution of seasonal changes in birch pollen count, especially the date of maximum values, is skewed to the left (skewness from -0.02 to -2.19 ); the majority of pollen grains appears in the air in the first half of the season. This phenomenon is confirmed by the values of the average and median date of maximum birch pollen count (Tab. 1). Seasonal maxima occur on average 1 week after the start of the pollen season (distribution significantly left-skewed). The values of maximum pollen counts from the whole study period show very high variation, up to $V=108 \%$. In extreme years, the highest birch pollen count differed from the lowest one by almost 108 times (Tab. 1).
The total sums of pollen (SPI) differed considerably in all seasons (negative values of the kurtosis) and ranged on average from 5631 to 15 932. The maximum SPI values were found in Lublin (the total sum of 33000 ), whereas the minimum values were recorded in Rzeszów (the total sum of 984). In most cases, the long pollen seasons of Betula are associated with a lower SPI value compared to the compact pollen seasons. Thus, short pollen seasons are characterized by higher intensity of pollination than long ones. This relationship has been confirmed by the analysis of Spearman's rank-correlation which showed a negative, statistically significant correlation between pollen season duration and SPI values (Tab. 1). 


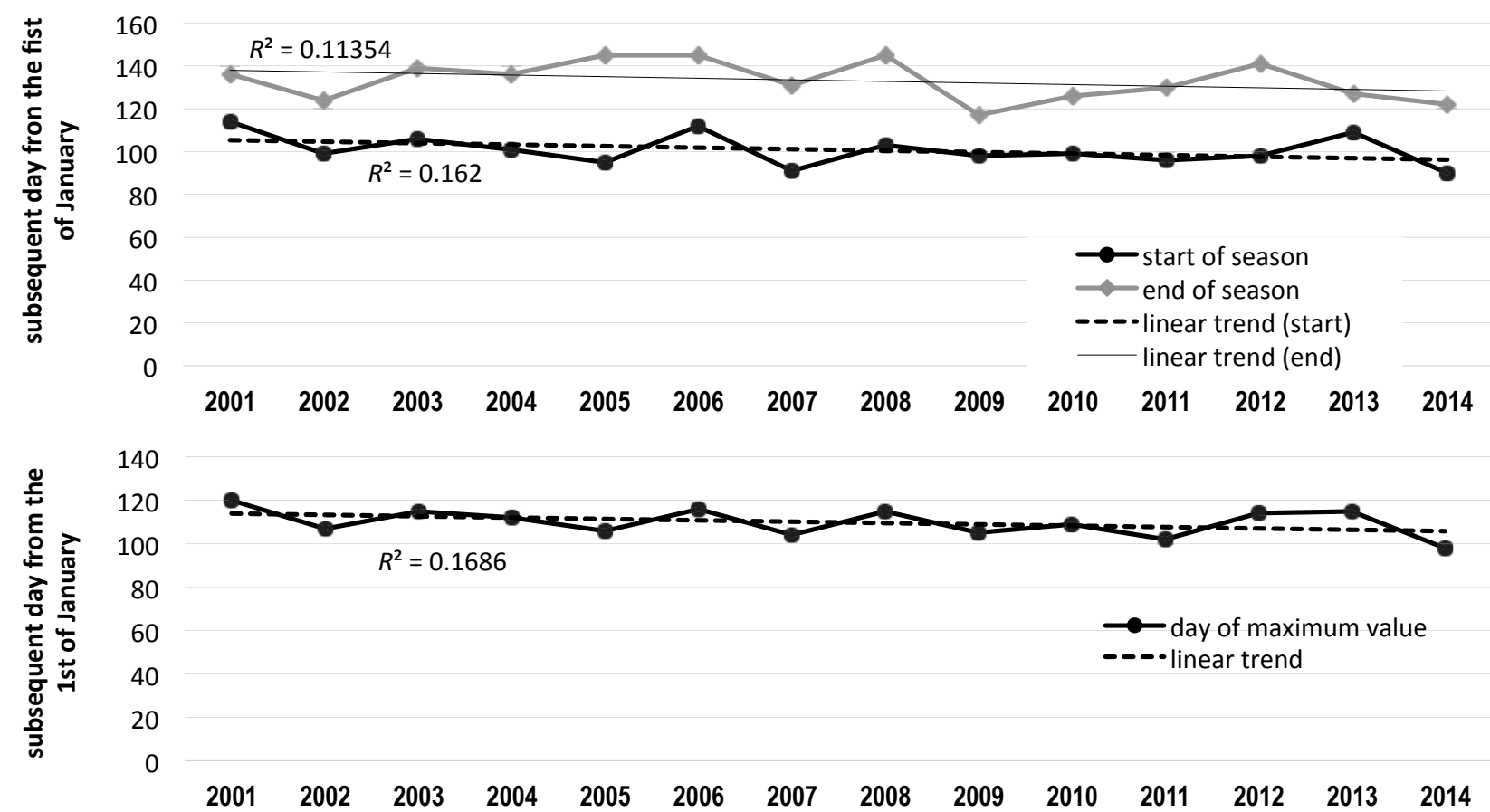

Fig. 1 Linear trends of selected features of birch pollen season in Szczecin.

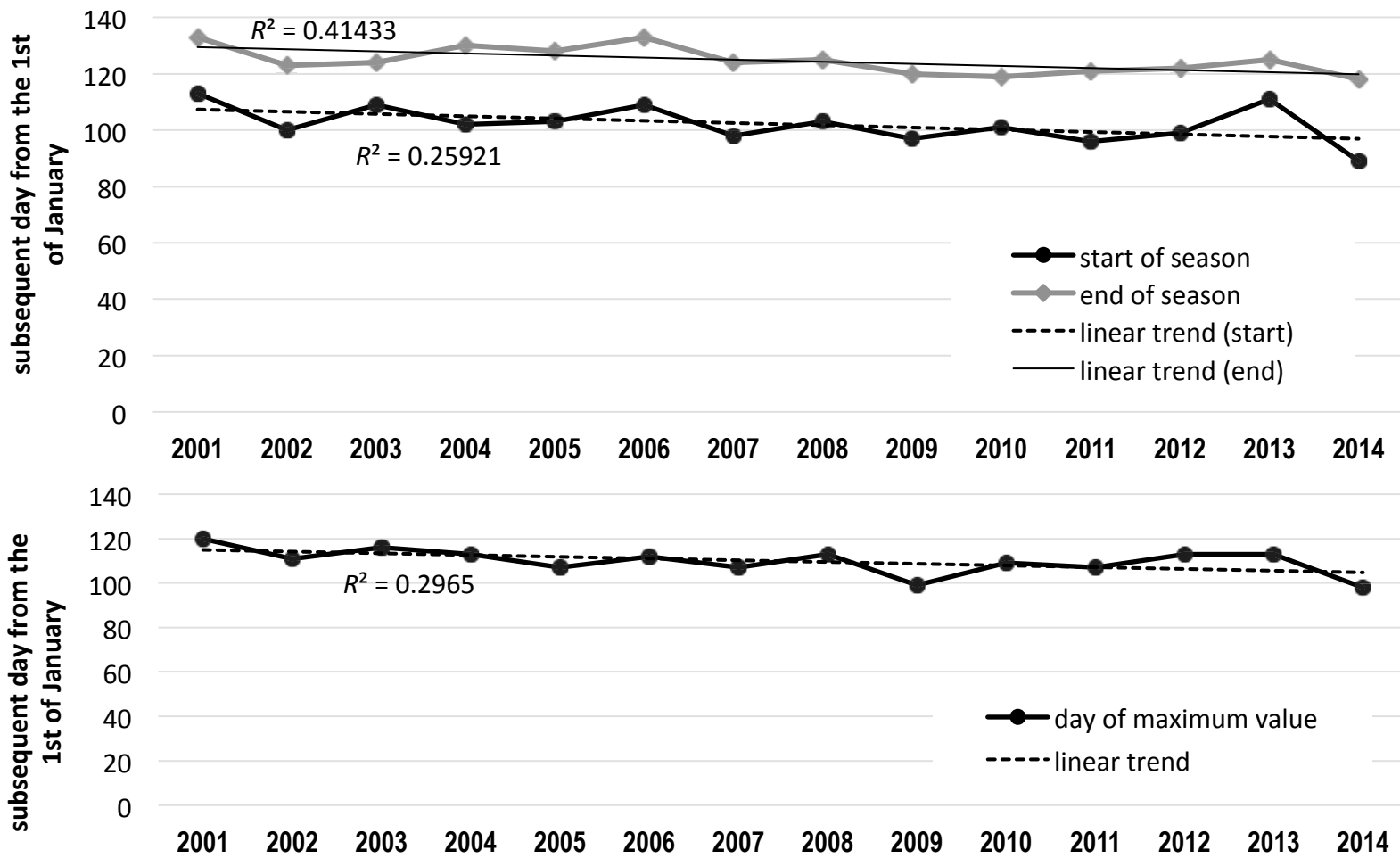

Fig. 2 Linear trends of selected features of birch pollen season in Poznań. 


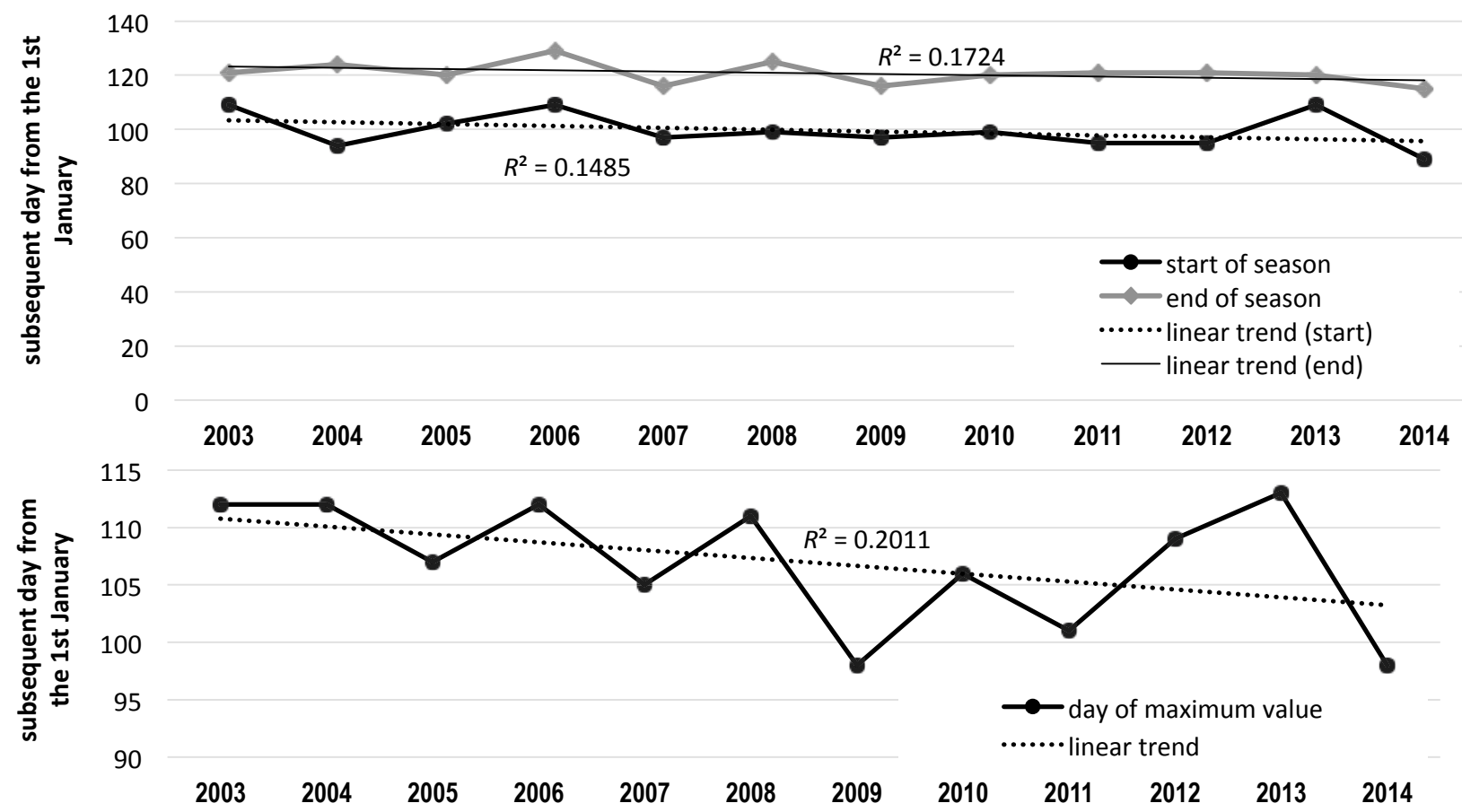

Fig. 3 Linear trends of selected features of birch pollen season in Wrocław.

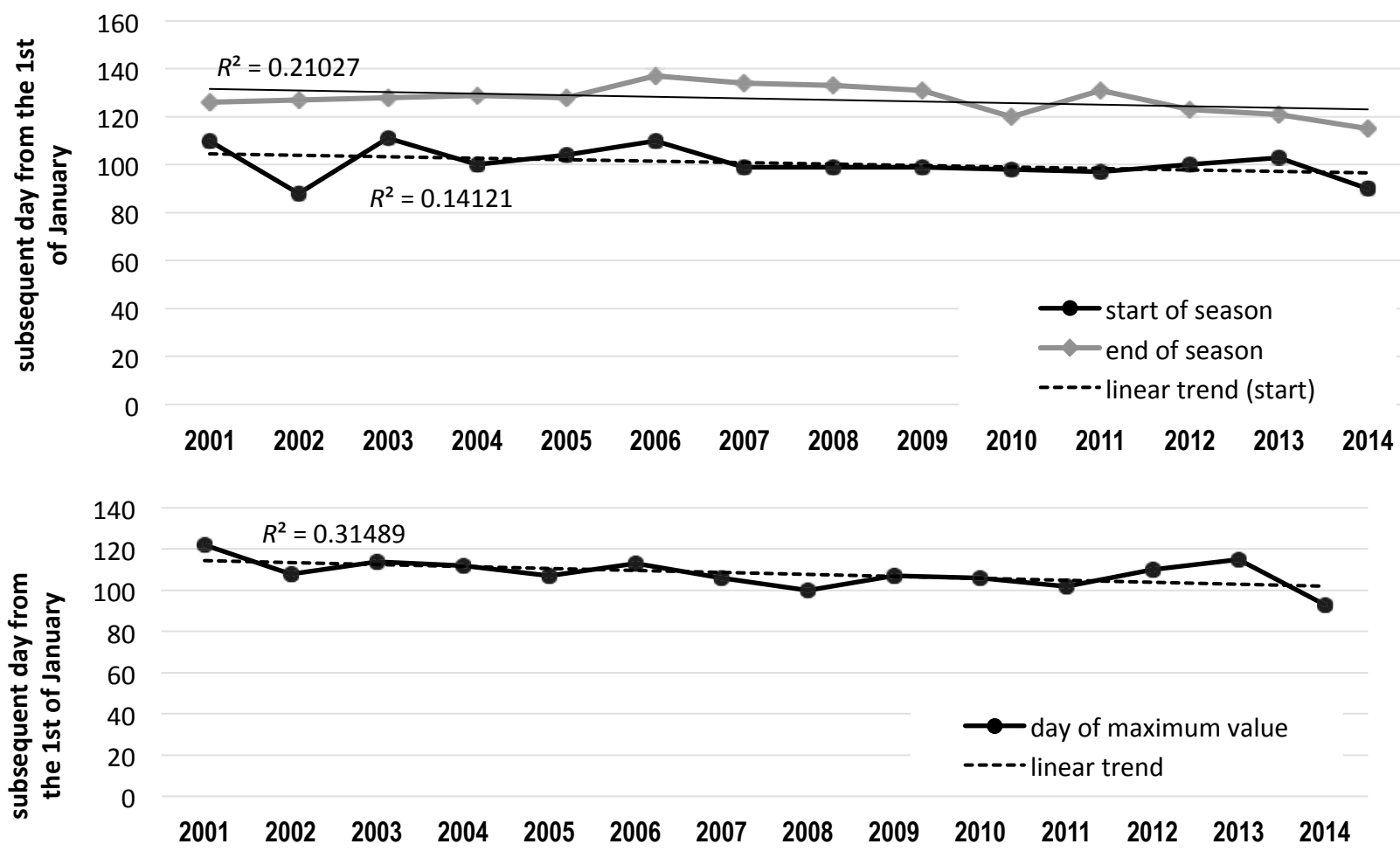

Fig. 4 Linear trends of selected features of birch pollen season in Kraków. 


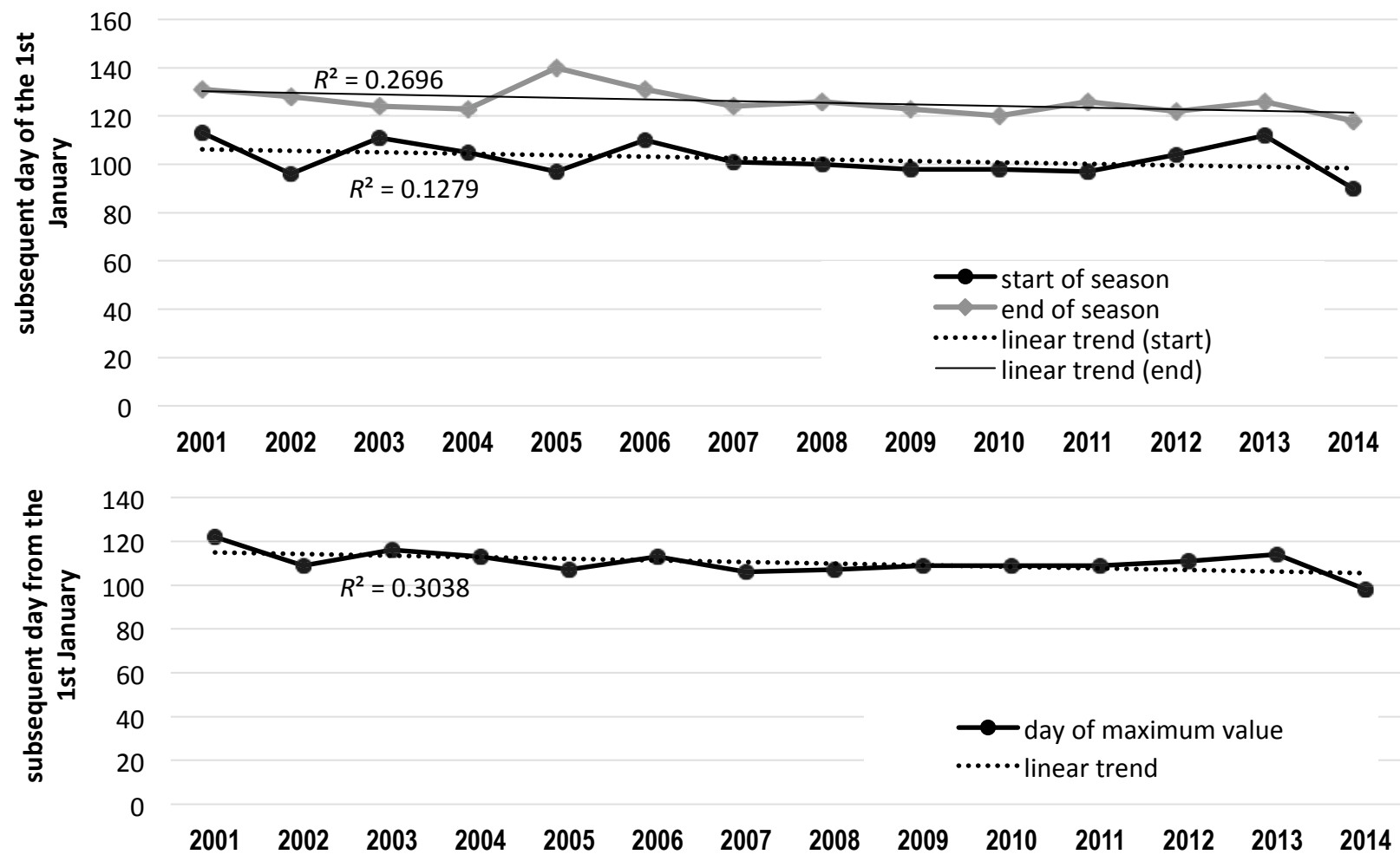

Fig. 5 Linear trends of selected features of birch pollen season in Sosnowiec.

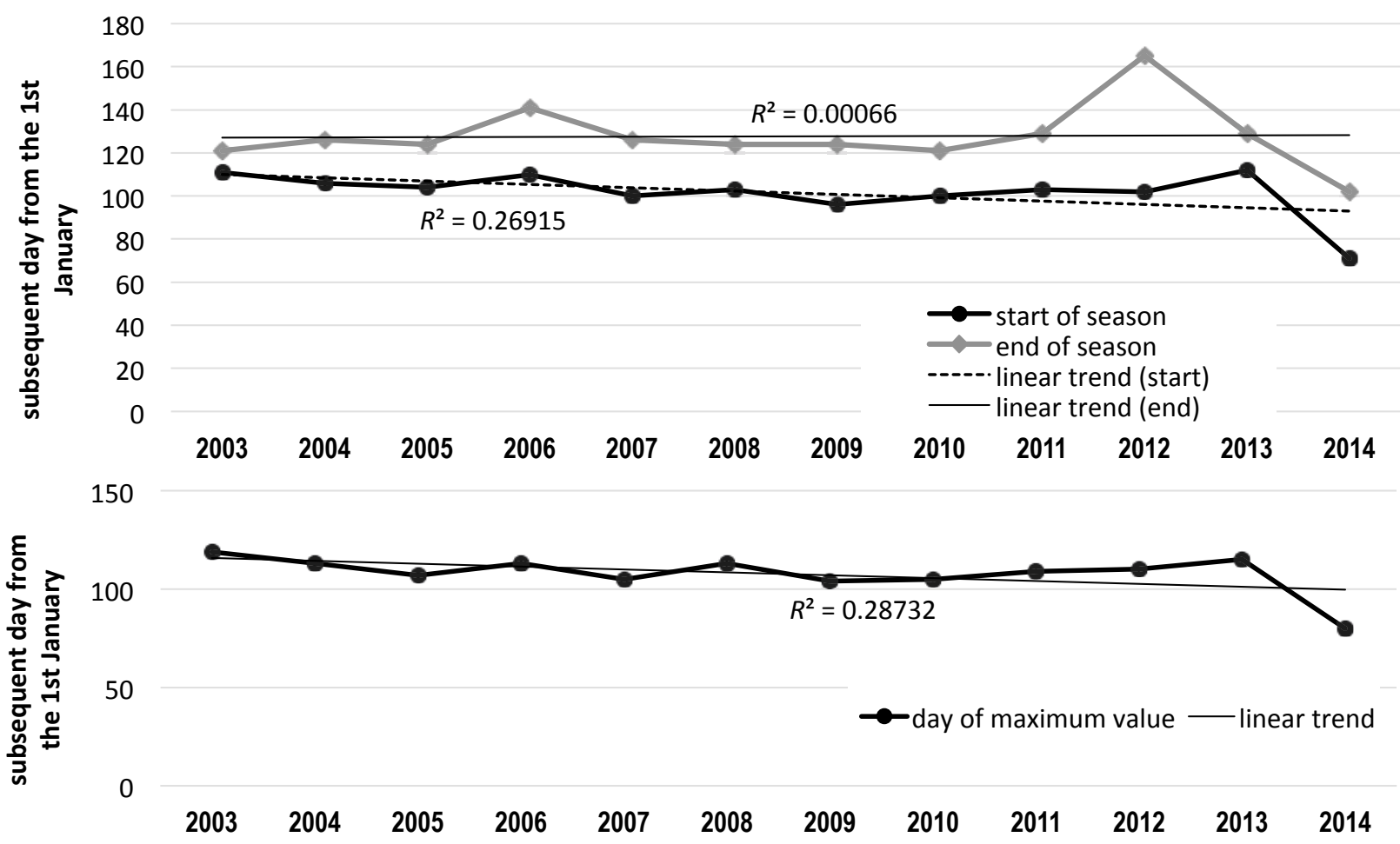

Fig. 6 Linear trends of selected features of birch pollen season in Łódź. 


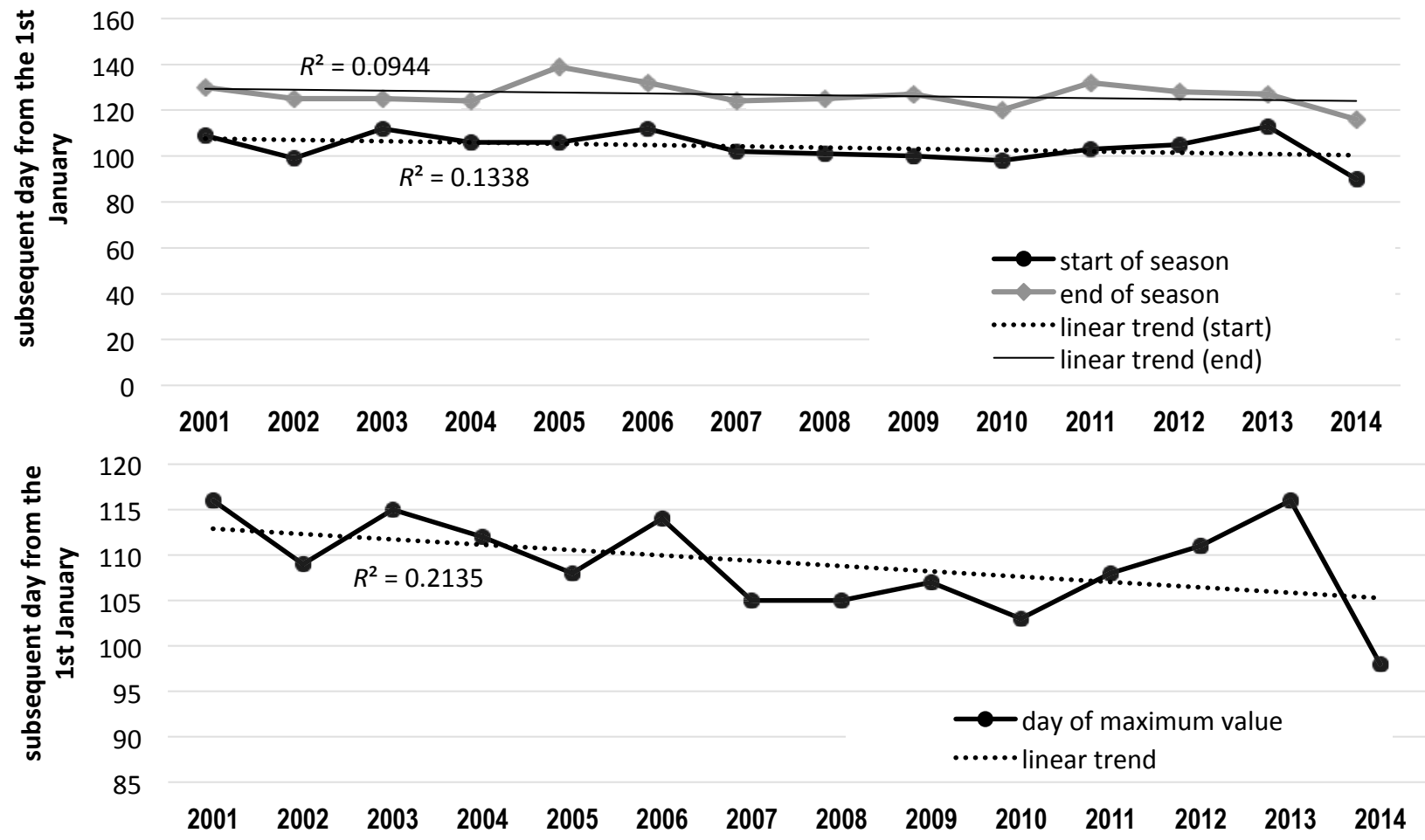

Fig. 7 Linear trends of selected features of birch pollen season in Lublin.

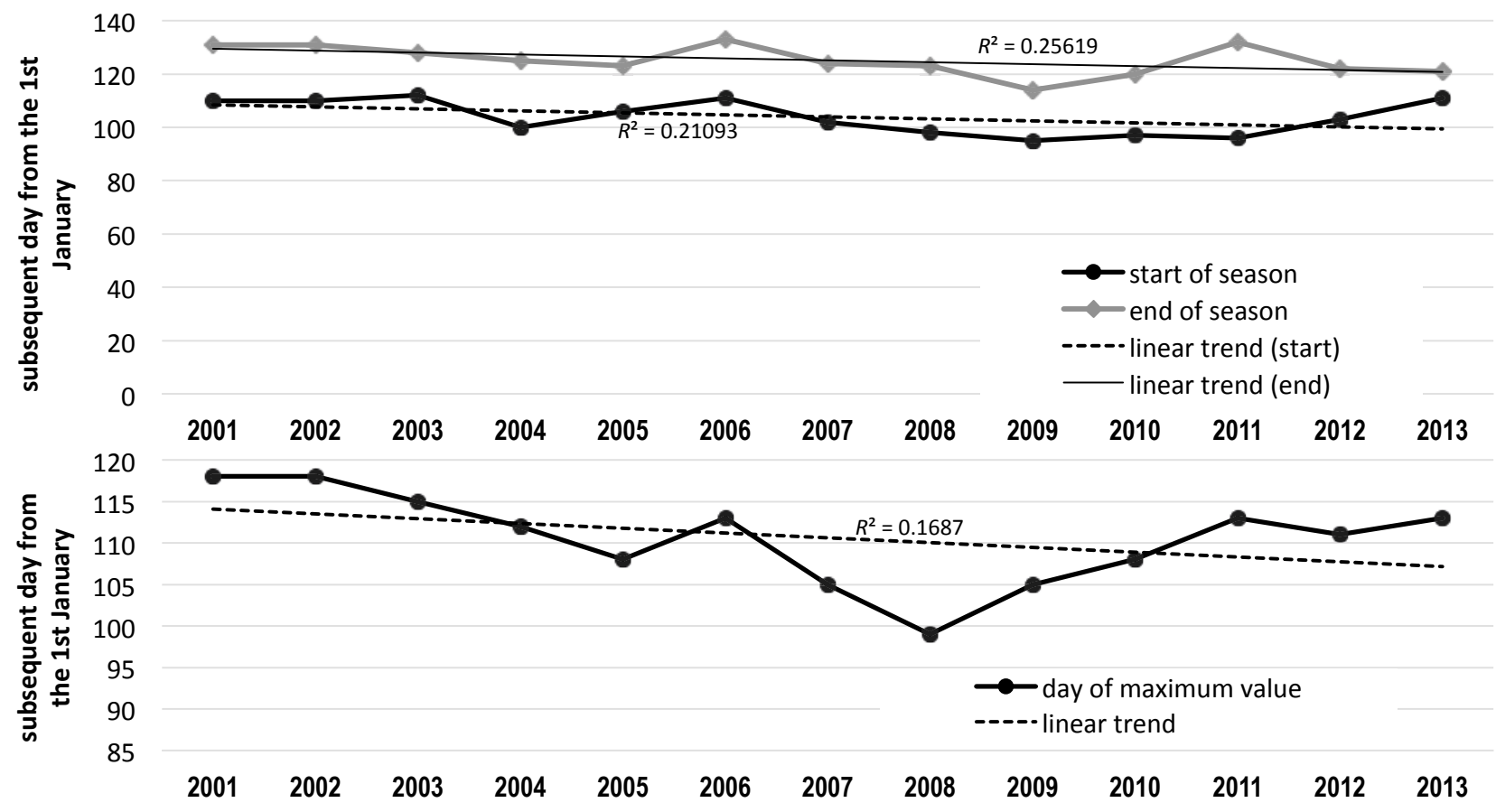

Fig. 8 Linear trends of selected features of birch pollen season in Rzeszów. 


\section{Trend analysis}

Trend lines (Fig. 1-Fig. 8) were used to illustrate the trends of selected features of birch pollen seasons and to analyze the issues related to prediction. By extending these lines beyond the set of available data, one can predict future values, inter alia, pollinosis-related prophylaxis.

During the fourteen-year study period, weak but statistically insignificant trends in the start of the Betula pollen season (occurring 7-10 days earlier) were observed; only in Szczecin a statistically significant trend was noted (Fig. 1-Fig. 8). Weak and statistically significant trends for the ends of pollen seasons (ending 7-10 days earlier) were found in Szczecin, Poznan, and Lublin. In the other cities, the trends for the season start and end were statistically insignificant and in Łódź a constant trend in pollen season ends was noted.

Throughout the whole study period, a weak increasing trend in pollen season duration was observed in Wrocław, Łódź and Lublin, but only in Lublin this trend was statistically significant. The values of the linear trend showed a good fit to the empirical data (41\%). In Szczecin, Poznań, Sosnowiec, and Rzeszów, the duration trend was constant.

A strong statistically insignificant trend towards a decrease in the maximum value was found for Szczecin, Wrocław, Sosnowiec and Łódź, and this decrease was 6-68\% in comparison to the average value of the seasonal maximum. In contrast, a statistically insignificant trend towards an increase in the maximum value was also observed for Poznan, Kraków, Lublin, and Rzeszów and this increase was 15-50\% in comparison to the average value of the seasonal maximum. Similar relationships were observed for SPI values.

Most often, statistically significant trends were observed for the date of the maximum value. A statistically significant seasonal maximum occurring 1-2 weeks earlier was noted in all the cities except studied, for Wrocław and Rzeszów.

\section{Correlations with meteorological parameters \\ and air pollution in Szczecin}

The pollen count values exhibited statistically significant correlations with the meteorological parameters. Spearman's correlation test was performed to identify the major variables that impact the dynamics of pollen concentrations (Tab. 2) Positive and statistically significant correlations were observed between the Betula pollen count and maximum air temperature, wind speed, and total radiation. A significant negative correlation was found between pollen count and relative humidity. The meteorological parameters analyzed were also strongly positively correlated to one another. The exception was relative humidity; this parameter was negatively correlated with most of the other meteorological parameters.

The correlation between wind speed and Betula pollen count was weaker than for the other weather parameters.

The correlation between air pollution and pollen concentration is shown in Tab. 2. The birch pollen counts are mainly positively and statistically significantly correlated with the concentration of the air pollutants studied. As far as the aggravation of allergy symptoms is concerned, the greatest threat is associated with the combined influence of pollen vs. nitrogen oxide and particulate matter. Positive, statistically significant correlations were observed between sulphur dioxide and carbon oxide concentrations and pollen count, but the relationship was weaker than for other parameters.

\section{Discussion}

The pollen count is determined by many factors and therefore long-term observations should be performed, while data analysis must include different aspects, in particular it should be related to prophylaxis of allergic diseases.

Depending on climatic conditions observed during a given calendar year, the periods of occurrence of pollen of particular plant species may differ between seasons by as much as 5 weeks [17]. Usually, the periods of pollen occurrence depend on thermal conditions in early spring, which occurs in Poland at the turn of winter and spring. The results on the daily distribution of seasonal pollen count from many countries have proved great diversity in the patterns of pollen release in anemophilous plants [12,18,19]. Pollen release is influenced by the local climate and geographical location. The dynamics and duration of pollen seasons as well as the kurtosis, variation coefficient, skewness and totals of pollen grains heavily depend on the geographical location [19], which was confirmed in our study conducted in 8 cities in Poland. Myszkowska et al. [19] also suggested that the higher counts of tree pollen in north-eastern Poland were prompted by its long distance transport and the prevalent wind from the west. Therefore, other patterns of tree pollen dispersal could be revealed depending on the region.

Aerobiological and aeropalynological analyses conducted worldwide, including Europe, allow one to establish the trends in pollen counts relating to the differences in the macro-scale. Jäger et al. [20] observed a slow increase in pollen counts of the Betula pollen seasons in Brussels (Belgium) and Leiden (Netherlands). Similar results were obtained in London [21]. Growth trends in annual totals of Betula pollen were also found in Delmenhorst (Germany), Helmond and Leiden (Netherlands), Brussels (Belgium), and Derby (United Kingdom) [20,21]. Carrying out phenological studies of plant pollination in urban industrial areas, Latorre [22] observed the occurrence of an anomalous pollination rhythm for B. pendula. This rhythm is characterized by twoyear fluctuation and does not depend or depends weakly on weather parameters. This phenomenon is also confirmed by other authors, e.g., Jato et al. [24], Latałowa et al. [11], and Jäger et al. [20]. Our results did not reveal such clear relationships. However, we noted growth trends in annual totals and maximum values across 4 cities (Poznań, Kraków, Lublin, and Rzeszów). On the contrary, in Szczecin, Wrocław, Sosnowiec and Łódź decreasing trends were revealed.

The beginning of Betula pollen seasons is mainly dependent on maximum and average air temperature and relative humidity. The potential number of pollen grains pivots on air temperature occurring in summer and autumn in the year preceding pollination when the development of anthers begins [25]. The study coordinated by Kasprzyk et al. [26] in Rabka, Zakopane, Kraków, Warszawa, Rzeszów, Ostrowiec Świętokrzyski, Poznań and Gdańsk revealed that 
the beginning of the Fraxinus season occurs in the first 10 days of April. Analogous results were obtained for birch pollen seasons.

The analyses of the influence of air temperature on the beginning and dynamics of birch pollen season were conducted over a span of twenty years in many European cities, inter alia in Turku, Vienna, London, Kiev, Brussels, and Zurich [1]. A tendency towards an earlier beginning of the birch season in consecutive years was found and this phenomenon is associated with climatic changes, as shown, inter alia, by an increase in air temperature in early spring. Analogous results were obtained in Gdańsk (northern Poland) [11], Copenhagen (Denmark) [27], and Neuchâtel (Switzerland) [18]. In this study, the start date of the Betula pollen season was observed 7-10 days earlier.

The analysis of Spearman's correlations and ANN network in Szczecin [28] revealed that humidity was most strongly and inversely proportional to the concentration of Betula. Significant positive correlations of rather low level were observed for maximum temperature, average temperature, minimum temperature, and precipitation. Similarly, in this study we observed a high correlation with relative humidity, but it was much stronger with maximum air temperature.

Atmospheric gas pollution can cause aggravation of symptoms of birch pollen allergy during the pollen season of this taxon. Dominguez-Vilches et al. [29] observed aggravation of pollinosis symptoms at high pollen counts and increased content of solid particles in the air. Cariñanos et al. [30] have evidenced that the seasonal maxima of pollen counts often coincide with increased content of non-biological particles in the air, which causes frequent and long-lasting allergy symptoms.

Nitrogen and sulphur oxides, ozone and other air pollutants interact with the surface of airborne pollen grains,

\section{Acknowledgments}

This study was carried out within the framework of the project No. NN305 321936 financed by the Polish Ministry of Science and Higher Education in the years 2009-2011 in all cities without Wrocław. Research supported also by Polish Ministry of Science and Higher Education as part of the statutory activities of the Department of Botany and Nature Conservation and Physical Oceanography Laboratory, University of Szczecin; Department of Botany and Department of General Ecology, University of Life Sciences in Lublin; Department of Clinical and Environmental Allergology, Jagiellonian University Medical College; Department of Environmental Biology, University of Rzeszów; Laboratory of Aeropalynology, Faculty of Biology, Adam Mickiewicz University in Poznań; Faculty of Earth Sciences, University of Silesia; Department of Immunology, Rheumatology and Allergy, Faculty of Medicine, Medical University of Lodz; Laboratory of Paleobotany, Department of Stratigraphical Geology, University of Wrocław.

\section{Authors' contributions}

The following declarations about authors' contributions to the research have been made: wrote the paper, statistical analyses, data interpretation: MP; meteorological and air pollution data: TW; design of the tables: DM; aerobiological data collection: MP, DM, IK, ICC, ŁG, MN, EWC, KPW, KC, KDZ, BMW, ZB, MM, AGG, AS, AK, KB.

\section{Competing interests}

The following declarations about authors' competing interests have been made: EWC is a honorary editor of the Acta Agrobotanica; AGG is associate editor of the Acta Agrobotanica; other authors: no competing interests. leading to grain damage or even changes in the structure of pollen allergens [31]. Exposure to increased levels of $\mathrm{NO}_{x}$ intensified the airway reaction in patients to allergens, measured as decreased pulmonary and upper/lower respiratory tract function [32]. For these reasons, it is necessary to make observations of pollen concentrations and gas air pollutants, especially in the period of pollination of plants whose pollen has strong allergenic properties, like birch.

\section{Conclusions}

The majority of birch pollen grains appear in the air in the first half of the season, whereas seasonal maxima occur one week after the start of the pollen season, on average.

Long Betula pollen seasons are characterized by a lower SPI value compared to the compact pollen seasons. Thus, short pollen seasons are marked by higher intensity of pollen release.

Statistically significant trends towards an earlier maximum pollen value were observed, since the maximum counts were noted 1-2 weeks earlier.

The correlation analysis of Betula pollen concentration with weather parameters demonstrated that maximum temperature, total radiation, relative humidity and wind speed are the main factors affecting pollen concentrations in the atmosphere.

Spearman's rank correlation test revealed strong correlations of the pollen count with nitrogen oxides and particulate matter as well as a weak correlation with carbon oxide and sulphur dioxide.

Air pollution can increase the chances of aggravation of allergy symptoms to birch pollen.

\section{References}

1. Emberlin J, Detandt M, Gehrig R, Jaeger S, Nolard N, RantioLehtimäki A. Responses in the start of Betula (birch) pollen seasons to recent changes in spring temperatures across Europe. Int J Biometeorol. 2002;46:159-170. http://dx.doi.org/10.1007/s00484-002-0139-x

2. Cotos-Yáñez TR, Rodriguez-Rajo FJ, Jato MV. Short term prediction of Betula airborne pollen concentration in Vigo (NW Spain) using logistic additive models and partially linear models. Int J Biometeorol. 2004;48:179-185. http://dx.doi.org/10.1007/s00484-004-0203-9

3. APG II system. An update of the Angiosperm Phylogeny Group classification for the orders and families of flowering plants: APG II. Bot J Linn Soc. 2003;141(4):135-140.

4. Zając A, Zając M, editors. Distribution atlas of vascular plants in Poland. Kraków: Laboratory of Computer Chorology, Institute of Botany, Jagiellonian University; 2011.

5. Dyakowska J. Podręcznik palynologii. Metody i problemy. Warszawa: Wydawnictwo Geologiczne; 1959.

6. D’Amato G, Spieksma FT. European allergenic pollen types. Aerobiologia. 1992;8:447-450. http://dx.doi.org/10.1007/BF02272914

7. Negrini AC. Pollen as allergens. Aerobiologia. 1992;8:9-15. http:// dx.doi.org/10.1007/BF02291321

8. Puc M. Characterisation of pollen allergens. Ann Agric Environ Med. 2003;10:143-149.

9. Jahn-Schmid B, Radakovics A, Luttkopf D, Scheurer S, Vieths S, Ebner C, et al. Bet v $1_{142-146}$ is the dominant T-cell epitope of the major birch pollen allergen and important for cross-reactivity with Bet v 1-related 
food allergens. International Review of Allergology and Clinical Immunology. 2005;116(1):213-219. http://dx.doi.org/10.1016/j. jaci.2005.04.019

10. Rapiejko P, Lipiec A, Wojdas A, Jurkiewicz D. Threshold pollen concentration necessary to evoke allergic symptoms. International Review of Allergology and Clinical Immunology. 2004;10(3):91-93.

11. Latałowa M, Miętus M, Uruska A. Seasonal variations in the atmospheric Betula pollen in Gdańsk (southern Baltic coast) in relation to meteorological parameters. Aerobiologia. 2002;18:33-43. http:// dx.doi.org/10.1023/A:1014905611834

12. Stach A, Emberlin J, Smith M, Adams-Groom B, Myszkowska D. Factors that determine the severity of Betula spp. Pollen season in Poland (Poznan and Krakow) and the United Kingdom (Worcester and London). Int J Biometeorol. 2008;52:311-321. http://dx.doi. org/10.1007/s00484-007-0127-2

13. Woś A. Klimat Polski. Warszawa: Wydawnictwo Naukowe PWN; 1999.

14. Hirst JM. An automatic volumetric spore trap. Ann Appl Biol. 1952;39:257-265. http://dx.doi.org/10.1111/j.1744-7348.1952. tb00904.x

15. Comtois P. Statistical analysis of aerobiological data. In: Mandrioli P, Comtois P, Levizzani V, editors. Methods in aerobiology. Bologna: Pitagora Editrice Bologna; 1998. p. 217-259.

16. StatSoft Inc. STATISTICA (data analysis software system), version 11.

17. Gniazdowski R, Klimas F. Wykorzystanie obserwacji palynologicznych i fenologicznych w ustalaniu szczegółowej etiologii pyłkowicy. Otolaryngol Pol. 1976;30:21-27.

18. Clot B. Trends in airborne pollen: an overview of 21 years of data in Neuchâtel (Switzerland). Aerobiologia. 2003;19:227-234. http:// dx.doi.org/10.1023/B:AERO.0000006572.53105.17

19. Myszkowska D, Jenner B, Puc M, Stach A, Nowak M, Malkiewicz $\mathrm{M}$, et al. Spatial variations in the dynamics of the Alnus and Corylus pollen seasons in Poland. Aerobiologia. 2010;26(3):209-221. http:// dx.doi.org/10.1007/s10453-010-9157-z

20. Jäger S, Spieksma FTM, Nolard N. Fluctuation and trends in airborne concentrations of some abundant pollen types, monitored at Vienna, Leiden and Brussels. Grana. 1991;30:309-312. http://dx.doi. org/10.1080/00173139109431985

21. Corden J, Millington W, Bailey J, Brookes M, Caulton E, Emberlin J, et al. UK regional variations in Betula pollen (1993-1997). Aerobiologia. 2000;16:227-232. http://dx.doi.org/10.1023/A:1007607307139

22. Latorre F. Differences between airborne pollen and flowering phenology of urban trees with reference to production, dispersal and interannual climate variability. Aerobiologia. 1999;15:131-141. http:// dx.doi.org/10.1023/A:1007523316024

23. Spieksma FTM, Corden JM, Detandt M, Millington MW, Nikkels $\mathrm{H}$, Nolard $\mathrm{N}$, et al. Quantitative trends in annual totals of five common airborne pollen types (Betula, Quercus, Poaceae, Urtica and Artemisia), at five pollen-monitoring stations in western Europe. Aerobiologia. 2003;19:171-184. http://dx.doi. org/10.1023/B:AERO.0000006528.37447.15

24. Jato VM, Méndez J, Rodriguez-Rajo J, Seijo C. The relationship between the flowering phenophase and airborne pollen of Betula in Galicia (N. W. Spain). Aerobiologia. 2002;18:55-64. http://dx.doi. org/10.1023/A:1014987325946

25. Garcia-Mozo H, Galan C, Gomez-Casero MT, Dominguez E. A comparative study of different temperature accumulation methods for predicting the start of the Quercus pollen season in
Cordoba (south west Spain). Grana. 2000;39:194-199. http://dx.doi. org/10.1080/00173130051084322

26. Kasprzyk I, Uruska A, Szczepanek K, Latałowa M, Gaweł J, Harmata $\mathrm{K}$, et al. Regional differentiation in the dynamics of the pollen seasons of Alnus, Corylus and Fraxinus in Poland (preliminary results). Aerobiologia. 2004;20:141-151. http://dx.doi.org/10.1023/ B:AERO.0000032951.25974.c9

27. Rasmussen A. The effects of climate change on the birch pollen season in Denmark. Aerobiologia. 2002;18:253-265. http://dx.doi. org/10.1023/A:1021321615254

28. Puc M. Artificial neural network models of relationships between Betula pollen and meteorological factors in Szczecin (Poland). Int J Biometeorol. 2012;56:395-401. http://dx.doi.org/10.1007/ s00484-011-0446-1

29. Dominguez-Vilches E, Carinanos P, Galan Soldevilla C, Guerra Pasadas F, Garcia-Pantaleon FI, Villamandos de la Torre F. Airborne pollen concentrations, solid particle content in the air and allergy symptoms in Cordoba (Spain). Aerobiologia. 1995;11:129-135. http:// dx.doi.org/10.1007/BF02738278

30. Cariñanos P, Galan C, Alcazar P, Dominguez E. Diurnal variation of biological and non-biological particles in the atmosphere of Cordoba, Spain. Aerobiologia. 1999;18:177-182. http://dx.doi. org/10.1023/A:1007590023585

31. Schäppi GF, Monn Ch, Wüthrich B, Wanner HU. Analysis of allergens in ambient aerosols: comparison of areas subjected to different levels of air pollution. Aerobiologia. 1996;12:185-190. http://dx.doi. org/10.1007/BF02447411

32. Barck C, Lundahl J, Hallden G, Bylin G. Brie exposures to $\mathrm{NO}_{2}$ augment the allergic inflammation in asthmatic. Environ Res. 2005;97:5866. http://dx.doi.org/10.1016/j.envres.2004.02.009

\section{Zmienność sezonów pyłkowych brzozy (Betula L.) w Polsce}

\section{Streszczenie}

Sezony pyłkowe brzozy charakteryzują się bardzo dużą zmiennością głównie w odniesieniu do daty początku sezonu oraz jego intensywności. Bardzo krótki czas trwania sezonu pyłkowego Betula L. sprawia, że właśnie te cechy sezonu są bardzo ważne w profilaktyce i leczeniu alergii wziewnej u osób uczulonych. Badania przeprowadzono metodą objętościową (Burkard i Lanzoni VPPS 2000). Sezony pyłkowe zdefiniowano jako okres, w którym wystąpiło $95 \%$ całkowitej rocznej sumy stężeń pyłku. W pracy analizowano trend liniowy wybranych cech sezonu, skośność, kurtozę i współczynnik zmienności (V\%). Większość ziaren pyłku brzozy pojawia się w powietrzu w pierwszej połowie sezonu, a maksima sezonowe notowane są średnio 7 dni po jego rozpoczęciu.

W ciągu 12-14 lat badań zaobserwowano przyspieszenie daty początku sezonu pyłkowego oraz daty wystąpienia wartości maksymalnego stężenia, średnio o 7-14 dni. Natomiast koniec sezonu notowano o 5-10 dni wcześniej, w porównaniu do danych wieloletnich. Dłuższe sezony pyłkowe Betula charakteryzują się niską wartością SPI, w porównaniu z sezonami krótkimi, ponieważ te ostanie cechują się z reguły większą intensywnością uwalniania pyłku. Analiza korelacji elementów pogody ze stężeniem pyłku brzozy w Szczecinie wykazała, że największy wpływ na koncentrację pyłku wywierają: temperatura maksymalna powietrza, całkowite promieniowanie, wilgotność względna i prędkość wiatru. Ponadto wykazano silną, istotną statystycznie korelację pomiędzy występowaniem pyłku brzozy w powietrzu a stężeniem tlenków azotu oraz słabą korelację z koncentracją tlenku węgla i dwutlenku siarki. Takie zależności pomiędzy badanymi czynnikami mogą wpływać na nasilenie objawów alergii u osób uczulonych. 